FACTA UNIVERSITATIS

Series: Physical Education and Sport, Vol. 17, No 2, 2019, pp. 247 - 258

https://doi.org/10.22190/FUPES190306024Z

Professional article

\title{
LEADERSHIP IN A CONTEMPORARY SPORTS ORGANIZATION
}

UDC 796.062:316.422

$796.01: 316.46$

\author{
Dragan Životić1, Radovan Ilić ${ }^{2}$, Jovan Veselinović ${ }^{2}$, Srećko Bačevac ${ }^{2}$ \\ ${ }^{1}$ Faculty of Physical Culture and Sports Management, Singidunum \\ University, Belgrade, Serbia \\ ${ }^{2}$ Faculty for Management in Sport, Alfa BK University, Belgrade, Serbia
}

\begin{abstract}
The aim of this paper is to give an overview of the characteristics, factors and organizational performance of leadership in a narrative manner. We live in a time of rapid, increasingly dramatic, far more complex and unpredictable changes, which have a significant effect on behavior, business and management in organizations. Such processes are most commonly referred to as "hyperchange", "hypercompetition", and "hyperturbulence". These processes take place in a period which is referred to as the "digital revolution", "information era", "digital economics", "internet economics", "net economics", "knowledge economy/knowledge society", "postindustrial society", "age of discontinuity", "time of uncertainty", "third wave", etc. The responses to the rapid change in the environment in which sports organizations perform their business and have a wider social mission, and which are increasingly discontinuous in their character, seek from managers to be transformational leaders. This implies that leaders have the capability to create a vision, mission, policy and strategy and their implementation, achieving a much greater overall value for consumers and large transformational shifts in the short term. In an environment which is more dynamic, unpredictable, or insecure, leadership change has become a more critical aspect of leadership study. Modern leadership concepts focus on the leadership that organizations and individuals need. The idea of a shared leadership, virtual, transformational and one that is based on elements of emotional intelligence, obtains the right of citizenship and becomes the dominant field of research in the field of modern corporate governance.
\end{abstract}

Key words: Leadership, Transformational Change, Sports Organizations

Received March 06, 2019/ Accepted October 04, 2019

Corresponding author: Jovan Veselinović

Faculty for Management in Sport, Alfa BK University, St. Palmira Toljatija 3, 11070 New Belgrade, Serbia

Phone: +381 112674164 •E-mail: jovan.veselinovic@alfa.edu.rs 


\section{INTRODUCTION}

The key leadership skill means dealing with people, the influence among people and goal-setting. Leadership occurs among and with the people, with the help of influence to achieve specific goals in sports. Influence means that the relationship between people is not passive, because it is essential to achieving the goal. Hence leadership can be defined as the ability to influence people toward the attainment of specified goals. At the core of its definition is the idea that leaders are involved with other individuals in the process of achieving goals. Leadership is a human activity that occurs reciprocally between people, and in this case between the members of a sports organization. Leadership is much more than an individual trait since it is a complex phenomenon in which the followers and the context have a very important role (Silva, 2016).

Leadership must now concentrate on motivating and supporting teams using tools that were not previously considered, but have become crucial in a globalizing environment. In order for a team to be attuned to success, a combination of attributes are required that include: clear objectives, shared leadership, clear roles and responsibilities, interdependent members, mutual encouragement, and trust between the leader and the team (Sohmen, 2013).

Leadership is a dynamic process that involves the use of power. Power is, thus, a significant factor that indicates the possibility of command by the leader. Leaders use power in order to have an influence on the performance of their co-workers.

The study of leadership attributes and behaviors should be used to improve leadership management, which is a complex task and requires a sympathetic appreciation of the required multi-dimensional roles.

Leadership is a process of inspiring others, members of a sports organization, to diligently and consistently work towards the attainment of specified sports goals. It involves running individuals and groups towards a common goal, towards something that is necessary and, from the standpoint of effort, towards something that is justified. Sport experts and professionals who work with athletes should have a high level of knowledge, competence and professionalism (Savić, Ranđelović, Stojanović, Stanković, \& Šiljak, 2018).

In order for someone to be a successful leader in inspiring and leading members of an organization, it is necessary to possess certain knowledge, experience and skills to work with certain aspects of motivation, communication, interpersonal relationships, teamwork and group dynamics. It is known that leaders play an important role in the process of motivating coworkers to work firmly in order to execute, complete, and fulfill important work tasks, as well as to foster a set of internal forces of individuals and intensify their efforts and activities in carrying out their tasks. In the process of managing people, motivation is influenced by the internal strength of individuals, such as work habits, aspiration, level of identification, social elements, etc. External factors include the payment system, the characteristics of the working environment, security, respect, etc. Successful management of employees implies the cultivation of internal factors, in terms of their strengthening and development, as well as a systematic improvement and control of external factors in accordance with the needs and expectations of individuals and the objective opportunities of the sport organization itself. In addition, it involves developing a motivational process through an efficient combination of different motivational factors.

If needs are defined and if employees have a desire to satisfy them at a higher level, leaders are in a position to direct their efforts and to create the conditions for achieving this. 
Searching for a method, in fact, represents the determination of the required scale of values and conditions that stimulate the behavior of members of the organization (Životić $\&$ Veselinović, 2010). As a result of engagement, there are more performance (results of work) and rewards for additional efforts in achieving goals. The last stage is the direction made in relation to the established state of needs in the first phase.

The aim of this paper is to give an overview of the characteristics, factors and organizational performance of leadership in a narrative manner.

\section{THEORETICAL CONSIDERATIONS}

\section{Characteristics of leadership}

Leading individuals through a sports organization takes place with the help of certain standards, procedures and processes that are formalized and appropriate to the character of individual tasks (Veselinović, 2012). Additionally, individual leadership takes place through influence, interaction and informal contacts that are maintained at different levels and conditions. Leadership through interpersonal relationships can be complementary and competitive. In complementary leadership there are real expectations to achieve a better performance, or a higher level of performance. In a competitive leadership process, the probability is to achieve smaller effects, and a lower level of planned performance. In order to avoid this, it is necessary to create conditions that reduce individual resistance, dissatisfaction or indifference. These conditions are created by decentralizing the organization, narrowing interpersonal interaction, removing certain barriers in communication, and creating networks that link homogeneous groups or teams in a sports organization.

There are five key functions of leadership, functions that need to be managed well. These functions are to create a vision, to set out strategy, to set objectives and lead towards performance, to influence and motivate people, and to facilitate change and nurture culture (Hoye, Smith, Nicholson, \& Stewart, 2018).

Leadership is particularly influenced by four interpersonal dimensions: the achievement of positive influences, that is, the development and maintenance of skills that are necessary to achieve a positive and convincing influence on the behavior of individuals; development and maintenance of skills necessary for constructive action in conflict situations; development and maintenance capabilities for bargaining with other people in order to create certain agreements, and the development and maintenance skills to work effectively with stress.

Leadership has a special role in the formation, maintenance and development of individual groups (Životić, 2007). The leader has the task of determining its goals and needs at the stage of an group formation, whether they are of economic or social nature; in the stage of maintaining the group to work on strengthening the cohesion of the group, moral values and the role of individuals, and to resolve the conflicts that arise and to remove their causes.

In the development of the group, the leader has the task of working on changes and adapting the group towards new visions and requirements, as well as to encourage group members to develop their competencies and opportunities. In addition, leadership has a special role in creating effective groups.

Difficulties arise because groups are composed of different individuals who have different personal traits, tendencies and aspirations. Hence, leaders face certain problems, 
such as aligning different styles of work, depreciating intolerance and removing barriers in communicating and communicating members of the group (Kotler \& Ferč, 2006). The group is efficient if it is able to achieve satisfaction, interaction, productivity and savings.

Group effectiveness depends on several different factors, such as structure, attitudes, values, and scope. i.e., group size (Životić, 1999). The measure of group efficiency is satisfaction, interaction, productivity and savings, as well as the achieved sports result. Organizational factors include structure, technology, material resources (raw materials, tools, equipment) and the nature, that is, character of production tasks. High performance teams (and teams) have the following characteristics: clear goals, results orientation, competent members and a cooperative climate and culture.

The leader should be prepared to develop novel and effective methods of timely and complete communication, team-building, negotiation, and conflict resolution alongside the technical aspects of schedules, risks, and resources (Sohmen, 2013).

Turnaround (reversal of performance in an organization from negative to positive) and crisis leadership are the areas that provide defining career moments for sport leaders. It is frequently in these situations that leaders are most visible and influential and are also expected to demonstrate highly effective leadership. Multiple examples exist of ways in which sport organizations have given back to communities in crisis. When Hurricane Katrina struck New Orleans in 2005, several New Orleans Saints players volunteered to assist with the rebuilding of homes destroyed by the storm. This activity provided needed help and goodwill, but also assisted in building a mutual respect on the part of the team and its fans that likely contributed to the subsequent turnaround of the team and Super Bowl championship (Scott, 2014).

In order for the leader to accomplish his tasks in the domain of motivation, interpersonal relations, teamwork and group dynamics, it is necessary to possess a key characteristic of the ability to have a vision (Chernatony \& McDonald, 2003). It involves anticipating the future and understanding the necessary actions for its realization. The principles of a visionary leader are to be the first (to encourage innovation and support individuals with ideas); to be enthusiastic - inspire others to participate in a shared vision through a personal example; to help others (to be a team idol and support the efforts of others); to give an example (to provide a role model as an example of how others can and should work); to celebrate success (to bring in emotion and work with your heart as much as your head).

In theory, there are different approaches toward the characteristics of leadership: firstly, it is an approach that takes into account the personal characteristics of an individual, an approach that takes into account the behavior of individuals in relation to those that lead, direct and influence, the approach that links the situational factors and the behavior of the leaders, and a perspective approach, in terms of imagination and vision (Chernatony \& McDonald, 2003).

Another concept and approach that has gained strength over the last decade is that of the "learning organization" and its importance to organizational leadership in the future. As complexity increases in all aspects of business and industry, organizations that create environments embracing continued learning and understanding of the forces and factors influencing business strategies and practices will likely be the organizations that best flourish in an increasingly interconnected and global economy. In these highly adaptable organizations, ongoing individual and group- or team-based learning, with people participating in formal 
learning opportunities and regularly exchanging ideas, is a critical element of an effective organization's culture (Scott, 2014).

\section{Factors of leadership}

The factors of leadership include the characteristics of individuals who want to be leaders, then the traits of followers, i.e. subordinates and characteristics of the environment.

The characteristics of individuals, leaders are: loyalty, vigor, a positive mental attitude, enthusiasm, security, vision, focus, interpersonal skills, supporting subordinates, problem solving, acceptability, flexibility, and self-management. Studies on leadership and sport organization culture in professional sport have only recently begun to appear in the academic literature. The type and strength of team culture are thought by many to play a significant, if not primary, role in overall team performance in sport.

In addition to the characteristics of leaders of great importance for the organization are the characteristics of the employees, that is, followers with whom the leaders need to achieve a certain vision. In that sense, the leaders should adjust the way in which coworkers work by establishing relationships that enable the leaders to communicate well in the direction of the planned tasks (Olins, 2003). In order to achieve leadership in an efficient way, it is necessary for the members of the organization to be motivated for work and taking responsibility; to have the necessary knowledge and experience and be ready to learn; to accept the goals of the organization, challenges and difficulties in their realization; to be capable for the teamwork, joint action and acceptance of a "collective" spirit and cooperation; to be tolerant and communicative; to be independent, susceptible and persistent and to work hard in order to achieve success and a career.

With such co-workers, leaders are able to achieve high demands, because through participation to expression come creative potentials and a readiness to accept risk and uncertainty.

The environment works at the level of internal factors and external factors, that is, imperatives that have irreversible consequences. Within the internal factors, the values, attitudes, knowledge and experience of the employees and their relation to the vision and aspirations of their leaders have the greatest influence. The external factors include technological, economic, social and political variables, on which little or no relatively small influence can be exerted. For the successful leadership of a sports organization, the key factor for being a leader is the ability of the leader to create opportunities for maximally successful integration of internal factors with the given situation in the environment (Kotler $\&$ Keller, 2006). The overall performance of the organization is influenced by four complex parameters of the environment:

a) leadership skills and predispositions of the leader, personal qualities, values and attitudes;

b) characteristics of employees, their values, knowledge and experience;

c) dominant values, attitudes and schemes of interpersonal interactions, influences; and

d) characteristics of the market, technology, economic policy, etc. 


\section{Organizational performance and leadership}

Organizational performance (p) is a function (f) of the cognitive characteristics of individuals, leaders and employees, such as attitudes, values, character, competence of leaders and employees, knowledge, skills and environmental impact - in terms of dominant values and the capacity for interpersonal interaction and external in terms of certain imperatives of the given situation. Therefore, $\mathrm{p}=\mathrm{f}$ (the qualities of leaders and employees, the competence of leaders and employees, culture and interpersonal capacities and the environment).

Personal characteristics (personality) affect the formation and expression of certain perceptions of individuals in the organization, impact on the identification of problems and their causes, and the attitude towards work and co-workers (Tomić, 2005). It is the leadership skills which seek to observe a certain phenomenon, to understand present circumstances, to explain and expose problems in an acceptable way, to be objective, without mysticism and prejudice. Over time, individuals acquire knowledge that allows the world and things to be seen in a certain way. Among other things, the system of values of individuals represents only a personal stance on what is good and what is of value, what is a priority and what is not. For some, money, or profit, is a measure of value. For others morality, justice and truth are above all values. Belief is an important dimension of personal values of individuals, because it expresses the relation of the individual to the truth, events in the past and the present. The values and beliefs of individuals form the basis of behavior within a sports organization (Tomić, 2001).

Individual skills are twofold - they can be acquired and inherited. Both are in the function of gaining co-workers to follow the leader and respect his ideas and vision. The leader will, by using his skill, influence individuals and, with their help, turn their vision into reality, into work, in a rational and in an acceptable way. It is universally accepted that modern sports require people with "leadership skills" because it is believed that they represent specific assets in the sports organization (Tomić, 1999). Leadership in a contemporary sport is highly valued. It is considered that the key competitive advantage in the future will be the ability of the leader to create the social architecture needed to generate intellectual capital. Intellectual capital refers to knowledge, ideas, innovations and to "knowhow". A combination of the right types of knowledge management strategy and intellectual capital will enhance a firm's global performance. That is, an alignment between the right forms of intellectual capital and knowledge management strategy can contribute to a firm's performance in the international context (Ling, 2013).

Modern organizations are experiencing more complexity and need for adaptability and change. The need for this flexibility is created not only by the political, social, and economic environments in which organizations now operate, but also by the growing diversity of people and ideas within organizations as well as internationalization and globalization (Scott, 2014). Today, the main task of leaders at all levels is to oversee the processes in which old, dysfunctional truths are abandoned, and at the same time, they prepare people and organizations to accept change, to love change and develop affection for it, along with innovations that are proposed, tested, modified, and adapted.

Leadership is associated with superior business performance. Leaders are elected or self-selected in order to determine the fate of a business in the economy. Leadership is important when a company needs a change, when it needs to deal with changes in the 
external environment, and when it is necessary to lead the process of change. Nowadays, leadership is regarded as the single most important factor in the modern economy.

Today, leadership is considered as a process completely different from management. It is seen as a process in which other people besides managers can be leaders and where the focus is on the interaction between leaders and co-workers. It is a relationship that aims at mutually achieving a common purpose, not just the purpose of the leader. Leadership is a process which seeks to make urgent changes, not just a process of achieving some basic temporary goals. Leadership creates the vital link between organizational effectiveness and people's performance at an organizational level (Jing, \& Avery, 2016).

Getting co-workers to accept change is a sign of leadership in a contemporary sports organization. Real leadership means finding a solution to adapt to changes in modern sports. Managers make their own decisions, and leaders use employees to find a common solution. It introduces some disturbances in sports organizations, because employees need to learn new roles. The method in which work is done within sports organizations is changing. The leader must always keep in mind the context and therefore it is not good that he only be engaged in implementing the solution. The leader must know how many employees are able to learn new methods of doing things. It is very important to create confidence that the job can be done in a new way.

If we observe two dimensions - the environment (internal and external) and time (present and future) - then we are given four essential roles of leaders (Thomson, 1993). The right leader is in the middle, because he should balance all these activities. The leader is the organizer of the direction in which the sports organization should be moving, he is the driving force of change and the catalyst of change in the sports organization. He acts as a speaker in the external environment and has the role of directing the team of coworkers to empower them to decide independently and to take action. All four roles define the work of a visionary leader and are all equally important for the success of a contemporary sports organization.

It is difficult to imagine a contemporary sports organization that could last for a long time without leadership. No organizational structure is complete, and leadership is exactly what fills the gaps that exist, because they cannot be planned in advance and foresee all activities and every decision. In addition, organizations operate in changing conditions regardless of the sports market, technology, legislation and other forces according to which the sports organization has to adapt. It is the leadership that needs to feel these changes and to make people adapt to it. Leadership can provide the "will", this spirit of communion by which an "inspired" group differs from another that is "thrombotic". Leadership represents the skill of influencing other people in order to cooperate and contribute in achieving the goals of a sports organization.

Leadership combines talent with the ability to impact other people - individuals, groups and organizations. Like management, leadership represents the skill to make other people do their job, with the difference that people share the same values and thoughts about strategy implementation and about the method which should be used (Radosavljević, 2002). Leaders create new ideas, approaches and methods and have the talent to get superior results from an average sports team. In order not to stand lonely at the top of the pyramid, it is necessary that leader's co-workers in the sport organization have the same culture. This is fundamental for understanding and trust which are needed to successfully overcome all problems encountered in the strategy implementation process. 
Leaders of sport organizations assume responsibility for addressing challenges that include, but are not limited to, (a) maintaining financial solvency or economic viability in increasingly uncertain circumstances; (b) successfully leading change or being expected to produce a significant organizational turnaround in a short time frame; (c) effectively navigating an increasingly litigious sport environment (especially in the United States); (d) addressing issues of diversity including racial and gender equity; (e) dealing with what many believe to be over-commercialization in sport, as well as athlete substance abuse and an overall decline in sportsmanship; and (f) navigating carefully through occurrences of ethical misconduct and occasional criminal behavior of employees or athletes (Scott, 2014).

When it comes to the necessary competencies that a manager and leader should possess, the following three competencies are highlighted:

1. Technical (profession knowledge);

2. Interpersonal (ability to work with people);

3. Conceptual (business thinking ability).

Motivation of co-workers and employees is one of the most important tasks of managers and leaders. Great efforts and energy must be invested in achieving the goals of the sports organization. Since leadership, or leadership as a management function, involves impact on employees, motivation is an integral part of their work. It refers to the investigation of the forces that trigger behavior. It is a management process that influences the behavior of people based on the knowledge of what "causes certain human behavior."

In modern conditions, motivation is becoming an increasingly important skill that leaders must effectively master to be successful.

Motivation and motivatorss deal with different forms of conscious behavior of people located between two extremes of two boundaries:

1. Reflex actions - which a man can hardly control, and

2. Acquired habits - which are the result of certain habits in behavior, upbringing or experience.

Motivation is a general term covering the whole class of other concepts such as: needs, desires, aspirations, instincts, tendencies, and so on. When we say that one of the tasks of the managers in sport and of the leader is to motivate employees, then this implies those actions that are supposed to satisfy these desires, aspirations, needs, and that in that way they will persuade employees to behave in a way that suits the company and the management needs.

Motivators are incentives, rewards, and factors that are introduced into the workplace situation in order to get employees to behave in a specific way for businesses, while satisfying their own desires. By introducing a motivator, it is possible to channel the behavior of employees by giving priority to certain needs, while pushing others. Motivators are, therefore, factors that influence behavior (Stefanović \& Stefanović, 2007). In a sports organization, managers and leaders must take into account the type of motivators that are desirable for employees and to be creative, to change, vary and adapt them.

Leadership is a concept vital to the transformation of a sports organization. It is a process in which a real change is desired, and not just a process to achieve a business goal. Leadership involves leaders and co-workers who want real change in a sports team. The direction of change must be the result of a planning process involving leaders and coworkers. 
Many of the challenges facing the sport industry today call for visions that emerge out of collective thinking and create a collective impetus for change within or across organizations. According to Goldsmith (2012), "change is critical" to survival in competitive sport, but "sport is incredibly conservative" and may be more resistant to change than other areas of society. Thoughtful and adaptable strategic thinking and strategic leadership are likely essential for sport organizations to survive, prosper, and effectively reach their goals now and into the future. When thinking of these forms of strategy development in today's sport industry environment, one can see how it could be difficult for a deliberate and long term strategic plan to effectively realize its original intentions without having to adapt or respond to changes and to internal or external forces during the implementation of the plan (Scott, 2014). The Nike Corporation is an example of an extreme complex adaptive system in sport. The success that Nike has achieved, as well as the challenges it has faced regarding criticism for child labor and working conditions in Third World countries, relates to the complex interaction of numerous economic and sociocultural factors all emerging concurrently in a global business environment.

Transformational leaders are interested in transforming sports organizations, inspiring and encouraging employees to focus on change. It is necessary for all employees to realize that incremental improvements will not lead to the desired situation and that transformation as a basic qualitative change is of great importance for increasing the competitiveness of the sports team. Effective leadership also involves motivation, management, inspiration, remuneration and analytical skills. When all these are present, the organizations record increased employee satisfaction that positively influences the productivity and the profits (Hurduzeu, 2015). Lencioni (2012) has proposed that effective leadership must be teambased and points out that "leaders who choose to operate as a real team willingly accept the work and sacrifices that are necessary for any group that wants to reap the benefits of true teamwork". He also argues that modern leadership teams must operate like basketball teams, with members who play together on the court and are mutually dependent and interactive.

The process of transformation takes place in several phases, and begins by observing the need for change, followed by the creation of a new vision and ending with the institutionalization of change. The first task for the transformational leader is to observe the need for change. It is important to determine the real concept for starting the transformational process. It is better to start before the crisis comes in anyway. Therefore, it is necessary to review the basic assumptions about the place and role of the sports organization in society. This is necessary in order to observe the impact and change in the environment from the standpoint of the sports team.

In contrast to organizations in most other industries, many sport organizations operate within a high-profile and visible public environment with multiple constituents who are keenly interested in and often emotionally attached to the organization. In addition, competitive sport teams and athletes at all levels typically attract significant media attention, spanning from the local newspaper, radio, or television to the national media and major broadcast networks. These aspects of sport organizations create additional challenges for leaders; they must be prepared to deal effectively with issues creating news that can travel around the world almost instantly (Scott, 2014). In 2011, at the University of California at Los Angeles (UCLA), the initial hiring of a defensive coordinator for the football program was rescinded the following day amid strong speculation that UCLA fans and boosters used social media such as blogs, wikis, Facebook, and Twitter to unleash a massive campaign 
against the hire, thereby putting pressure on the athletic department to change its decision. While this was likely not the only reason for officials to change their hiring decision, it points out how quickly and powerfully a contingent of followers can mobilize and put external pressure on leaders of sport organizations (Sports by Brooks, 2011).

Awareness of the need for change is the starting point for initiating transformational changes. The process involves a good diagnosis of the problem to determine what kind of change is needed. What is most complex for leaders is to abandon old beliefs and values that were obstacles to initiate change (Živković, 2009). The changes alter the distribution of power and status within the sports organization, and may endanger the status and career of some people. Almost everyone has to learn new ways of behaving. The transformation leader helps people to accept the need for change and positively influences their self-esteem and optimism.

Transformational leadership is a complex and difficult task. In order to achieve this, it is necessary to respond quickly and resolutely, create a sense of urgency; to create and communicate a vision and plan; to extend objectives and empower others to assume responsibility and to take action to institutionalize change.

The transformational leader has a clear vision of the future status of his sports organization. He is a kind of social architect of his sports team, he creates confidence among his co-workers, making his position clear and maintaining it throughout the transformational process. He is a strong role model for his co-worker. He not only creates a vision, but he is also the main actor of the change.

\section{CONCLUSION}

Contemporary and future sports organization will face more and more turmoil, turbulent situations and chaos in businesses. The world of changes in which humanity is now proceeds with the exponential trend and huge fears for the survival of companies. The world is increasingly confronted with the terrible uncertainty of the future and the changes that are becoming of value. A new approach is needed in strategic problem solving and decision making when it comes to sports organizations, especially professional sports teams and multinational sports corporations. The complexity of the problem necessitates the appropriate level of knowledge of sports leaders, who should be able to carefully consider ideas and problems and make decisions for the benefit of all employees. In such circumstances, the survival of sports organizations, that is business, is related to expressing higher efforts, which we call the ability to create new, untested roads and ideas in order to success and achieve adequate sports results.

\section{REFERENCES}

Chernatony, L., McDonald, M. (2003). Creating powerful brands in consumer, service and industrial markets. Elsevier, Butterworth Heinemann

Goldsmith, W. (2012). Ten reasons why change is so hard to introduce in sport. www.sportscoachingbrain. com/ten-reasons-why-change-is-so-hard-to-introduce-in-sport.

Hoye, R., Smith, A.C., Nicholson, M., \& Stewart, B. (2018). Sport management: principles and applications. Routledge 
Hurduzeu, R.E. (2015). The impact of leadership on organizational performance. SEA-Practical Application of Science, 3(7), 289-293.

Ivashchenko, O., Yarmak, O., Galan, Y., Nakonechnyi, I., \& Zoriy, Y. (2017). Leadership as a fundamental aspect of the performance of student-athletes in university men's sports teams. Journal of Physical Education and Sport, 17 (Suppl. 2), 472-480.

Jing, F.F., \& Avery, G. C. (2016). Missing links in understanding the relationship between leadership and organizational performance. The International Business \& Economics Research Journal (Online), 15(3), 107.

Kotler, F., \& Ferč, V, (2006). B2B Brend menadžment (B2B Brand Management). Asee, Novi Sad. In Serbian

Lencioni, P. (2012). The advantage: Why organizational health trumps everything in business. San Francisco: Jossey-Bass.

Ling, Y.H. (2013). The influence of intellectual capital on organizational performance-Knowledge management as moderator. Asia Pacific Journal of Management, 30(3), 937-964.

Olins, W. (2003). On brand, Thames \& Hudson, London.

Radosavljević, Ž. (2002).Teorija, praksa i veština savremenog menadžmenta (The theory, practice and skill of contemporary management). DP Pronalazaštvo, Belgrade. In Serbian

Savić, Z., Ranđelović, N., Stojanović, N., Stanković, V., \& Šiljak, V. (2018). The sports industry and achieving top sports results. Facta Universitatis, Series Physical Education and Sport, 15(3), 513-522.

Scott, D. (2014). Contemporary leadership in sport organizations. Champaign, IL: Human Kinetics

Silva, A. (2016). What is leadership?. Journal of Business Studies Quarterly, 8(1), 1.

Sohmen, V. S. (2013). Leadership and teamwork: Two sides of the same coin. Journal of IT and Economic Development, $4(2), 1-18$

Sports by Brooks (2011). UCLA Fan Sites Killed Defensive Coordinator Hire. Retrieved from www.sportsbybrooks.com/ucla-fan-sites-kill-asst-football-coach-hire-29478

Stefanović, N., \& Stefanović, Ž. (2007). Liderstvo i kvalitet (Leadership and quality). Faculty of Mechanical Engineering, Quality Center, University of, Kragujevac. In Serbian

Thomson,J.L. (1993). Strategic Management, Chapman and Hall.

Tomić, M. (2005). Adhokratija kao pristup u dizajniranju organizacione structure sportske organizacije I njen uticaj na stvaralaštvo I inovacije u sportu (Adhocracy as an approach in designing the organizational structure of a sports organization and its impact on creativity and innovation in sport), Proceedings of the $1^{\text {st }}$ International Scientific Conference "Management in Sport", University "Braća Karić", Faculty of Management in Sport, Belgrade. In Serbian

Tomić,M. (2001). Menadžment u sportu, (Management in sport). IP „Astimbo“, Belgrade. In Serbian

Tomić, M. (1999). Menadžment u sportu (Management in sport). CPS, Belgrade. In Serbian

Veselinović, J. (2012). Menadžment sportske organizacije (Management of sports organizations). Belgrade: Sports Association of Serbia.

Živković, S. (2009). Liderstvo u sportu (Leadership in sports). Belgrade: Alfa University, Faculty of Trade and Banking "Janićije and Danica Karić". In Serbian

Životić, D. (2007). Menadžment u sportu (Management in sports). Belgrade: Alfa University, Faculty of Management in Sport. In Serbian

Životić, D. (1999). Upravljanje u sportu (Management in sports). Belgrade: Ministry of Sport and Youth of the Government of the Republic of Serbia. In Serbian

Životić, D., \& Veselinović, J. (2010). Modeli funkcija u sportskom menadžmentu (Function models in sports management). Belgrade: Alfa University, Faculty of Management in Sport. In Serbian

\section{LIDERSTVO U SAVREMENOJ SPORTSKOJ ORGANIZACIJI}

Cilj ovog rada je da se narativnim putem pruži pregled karakteristika, faktora i organizacionih performansi rukovođenja. Živimo u vremenu sve bržih, dramatičnijih, kompleksnijih i nepredvidljivih promena koje sve značajnije utiču na ponašanje, poslovanje i upravljanje u organizacijama. Za takve procese upotrebljavaju se izrazi: hiperpromene (hyperchange), hiperkonkurencija (hipercompetition) $i$ hiperturbulentnost (hiperturbulens). Ovi procesi dešavaju se u periodu koji se označava kao „digitalna revolucija“, „informaciono doba“, „,digitalna ekonomija“, „Internet ekonomija“, „,Web ekonomija“, „ekonomija znanja“, „društvo znanja“, „postindustrijsko društvo“, ,,doba diskontinuiteta“, „doba 
neizvesnosti“, „treći talas“, i slično. Odgovor na ubrzanje promena, u sredini u kojoj sportske organizacije obavljaju svoju poslovnu i širu društvenu misiju, koje imaju sve više diskontinuelni karakter, traže od menadžera da budu krupne transformacione zaokrete u kratkom roku. Ako je okruženje dinamičnije, nepredvidljivo transformacioni lideri. To podrazumeva da imaju sposobnost kreiranja vizije, misije, politike $i$ strategije $i$ njihove implementacije, pri tom postižući znatno veću opštu vrednost za konzumente $i$ inesigurnije, promena vođstva postala je kritičniji aspekt studiranja liderstva. Moderni koncepti liderstva fokusiraju se na liderstvo koje je potrebno organizacijama i individuama. Ideja deljenog liderstva, virtuelnog, transformacionog $i$ zasnovanog na elementima emotivne inteligencije, dobija pravo građanstva, i postaje dominantno područje istraživanja u oblasti upravljanja savremenim korporacijama.

Ključne reči: liderstvo, transformacione promene, sportske organizacije 